\title{
Valuation of recreational fishing benefits: A snapshot from Ordu, Turkey
}

\section{Rekreasyonel balıkçılığın faydalarının değerlemesi:: Ordu örneği}

\author{
Mehmet Aydın1 ${ }^{1}$ Sezgin Tunca2* ${ }^{*}$ Uğur Karadurmuş ${ }^{1} \cdot$ Denizcan Durgun $^{3}$
}

\author{
1 Ordu University, Fatsa Faculty of Marine Sciences, 52400, Fatsa, Ordu, Turkey \\ 2 Department of Marine Sciences and Applied Biology, University of Alicante, 03080, Alicante, Spain \\ ${ }^{3}$ Ege University, Faculty of Agriculture, Department of Agricultural Economics, 35100, Bornova, Izmir, Turkey \\ ${ }^{*}$ Corresponding author: sezgin.tunca@gmail.com
}

\begin{abstract}
Özet: Kıyısal alanlarda rekreasyonel balıkçılık Türkiye'nin ekonomik gelişiminde önemli bir rol oynamaktadır. Bu çalışmada, Ordu ili’nde rekreasyonel balıkçılı̆ın pazardışı ekonomik değeri Koşullu Değerleme (31,500 Türk Lirası: TL) ve Seyahat Maliyeti $(504,000$ TL) Yöntemleri kullanılarak hesaplandı. Tobit Regresyon Model ile ödeme istekliliğine etki eden faktörler ve Negatif Binomiyal Regresyon Model ile bireysel seyahat maliyetine etki eden faktörler değerlendirilmiştir. Pazardışı faydaları belirlemenin yanında, rekreasyonel balıkçıların balıkçılık, demografik ve sosyoekonomik özellikleri rekreasyonel balıkçıığın yapısını daha iyi anlamak üzere sorgulanmıştır. Sonuç olarak, Ordu Illinde rekreasyonel balıkçılığın büyük bir ekonomik etkisi bulunmaktadır
\end{abstract}

Anahtar kelimeler: Rekreasyonel balıkçılık, ekonomik değer, koşullu değerleme yöntemi, seyahat maliyeti yöntemi, Ordu illi

Abstract: Recreational fishing in coastal areas plays an important role in the economic development of Turkey. In this study, non-market economic value of recreational fishing activities by using Contingent Valuation (31,500 Turkish Liras: TL) and Travel Cost (504,000 TL) Methodologies was calculated in Ordu Province. The factors affecting the respondent's Willingness-to-Pay via Tobit Regression Model and the factors affecting individual travel cost via Negative Binomial Model was assessed. Beside determining non-market benefits, socioeconomic, demographic and fishing dimensions of recreational fishermen were also queried to provide better understanding of recreational fishing profile. In conclusion, it was determined that recreational fishing in Ordu has economically big impact in the region.

Keywords: Recreational fishing, economic value, contingent valuation methodology, travel cost methodology, Ordu Province

\section{INTRODUCTION}

Ordu, with its ancient name Kotyora, is a harbor city located in the Black Sea Region of Turkey. The principal economic activities of Ordu are agricultural production mainly hazel nut and fisheries. The city has 714,390 population and it is highly populated along the coastline districts including city center, Perşembe, Fatsa, Ünye where the populations are $32,894,9,276,100,303$, and 114,408, respectively (TSI, 2011).

Recreational fishing in the coastal areas, which have high total economic value, including use and non-use values, may play an important role in the economic development of Turkey. The country's coast stretches over $8,333 \mathrm{~km}$ and contains a variety of ecosystems may also contribute the number of activities.

Coastal marine zones host economically important areal uses including touristic, cultural, aesthetic and recreational. Short-term financial benefits from economic activities in the coastal zone, in particular those from tourist/recreational activities, are potentially high (Steijn et al., 2012). Coastal recreation activities, which have been increasing both in volume and in number during the last decade, occupy a unique place in coastal tourism (Markovic et al., 2009).
Recreational fishing in the coastal zones is basically an open access activity, considered different from professional/commercial fisheries because they are not subject to the market economic forces (Morales-Nin et al., 2008). However, recreational fishing is particularly important in the Mediterranean, representing more than $10 \%$ of total fisheries production in the area (EU, 2004) although recreational fishing was not recognized (Ünal et al., 2010). Researchers reported that in Mediterrannnean There is also very important and increasing popular recreational fishery, with more than 2,106 anglers and 300,000 recreational fishing boats (Morales-Nin et al., 2005).

There are different authorities including European Union supported by the General Fisheries Commission for the Mediterranean, Food and Agriculture Organization, and national fisheries authorities, regional governments supporting the management of recreational fishing in the Mediterranean.

Recreational fishing is a major economic driver; overall economic impact of angling in the United States of America being 125 billion United States Dollars (USD), and in Europe the annual expenditure by anglers is an estimated 25 billion Euros (Hickley and Tompkins, 1998). In United States, RF 
generates 4.9 billion USD trade, 47,000 jobs in the West Florida; 3.3 billion USD trade and 29,000 jobs in the East Florida; 2.2 billion dollar trade and 18,000 jobs in Louisiana; 1.9 billion dollar trade and 15,000 jobs in Texas and 1,7 billion dollar trade and 10,000 jobs in New Jersey (NOAA, 2013).

Today, there is a number of valuation techniques to monetize the demand rising from recreational fishing. Current economic valuation techniques can be divided into three subcategories: 1) revealed preference approaches (e.g. travel cost (TC), market methods, hedonic methods and production approaches) 2) stated-preference approaches (e.g. contingent valuation (CV), conjoint analysis), and 3) cost-based approaches (e.g. replacement cost, avoidance cost) (Gaudin and De Young, 2007; Parkkila et al., 2010).

The main objective of this paper was to calculate nonmarket economic value of recreational fishing in Ordu province. It was also aimed to examine the factors affecting the respondent's willingness to pay (WTP) via tobit regression model and the factors affecting individual TC via count regression analysis in Ordu. In addition to determining nonmarket benefits via CV and TC methodologies, socioeconomic, demographic and fishing related dimensions of recreational fishermen were also queried to provide better understanding of recreational fishing profile in Ordu.

\section{MATERIALS AND METHOD}

\section{Study site}

Questionnaire surveys were conducted in Ordu that has $100 \mathrm{~km}$ coastline and boat-based recreational fishing to 630 licensed recreational fishermen in province according to the national statistics (FIS, 2011). In addition, owing a recreational fishing license is not compulsory for Turkish citizens; however, anyone who wants to own a recreational fishing license may own it from provincial directorates of ministry (Anonymous, 2012).

Popular recreational fishing destionations were determined as Center of Ordu, Perşembe, Fatsa and Ünye where shore-based and boat based recreational fishing activities are common (Figure 1). In addition, the littoral zone of Ordu is composed of sand dunes and affected by a great amount of fresh water streams which supplies feeding and reproduction areas for many marine species.

\section{Data Collection}

The target survey groups were identified as 120 recreational fishermen who participate in recreational fishing onshore or from a boat. Total number of recreational fishermen in Ordu is not known and it is hard to find all recreational fishers because of the inexistence of a recreational fishing organization therefore, snowball sampling methodology was used to determine the sampling size (Miran, 2003). Generally, to be apparent for 4 study areas, 120 recreational fishermen were sampled in 2011. For each study location on the map, 30 recreational fishers were queried.

\section{Data Analysis}

\section{Tobit Regression Model}

Tobit regression model is placed among limited dependent variable models (Gujarati, 2004). In this model, dependent variable, $Y$ holds an asymmetry between positive and negative or 0 values. Common formulation of tobit regression model is given based on an index function below (Equation 2) (Ramanathan, 1998; Greene, 2000).

$$
Y_{i}^{*}=\beta^{\prime} x_{i}+u_{i}, \quad \text { (Equation 2) }
$$

If $Y_{i}^{*} \leq 0$ ise, $Y_{i}=0$;

If $Y_{i}^{*}<0$ ise, $Y_{i}^{*}=0$

Estimators in a tobit regression model are calculated by maximum likelihood method (Gujarati, 2004). In this study, tobit regression model was used to determine relationships between the amount of WTP and dimensions of the respondents including socioeconomics, demographics and fishing.

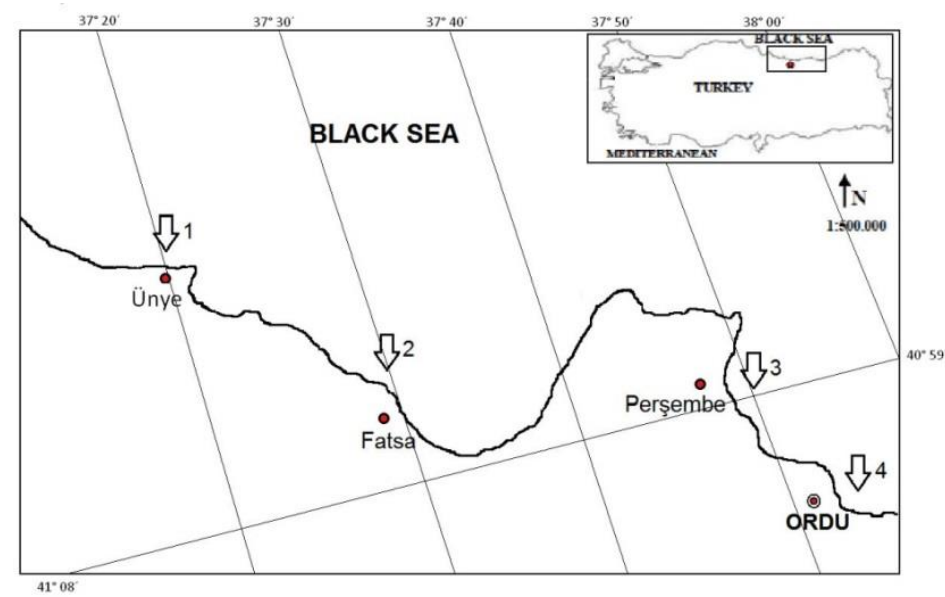

Figure 1. Location of the study area on the map 


\section{Contingent Valuation Method}

A hypothetical marketplace is created in the CV method, which was used successfully to study unchangeable goods in the market (Haab, 2002). In a CV study, the main aim is to create a scenario related to any environmental good or service, and respondents are asked their WTP for an increase in the quantity and quality of the good or service (Parkkila et al., 2010). There are some different offer formats for questions used to determine WTP, such as open-ended, dichotomous choice, bidding game or payment cards (Bateman and Willis, 2002; Wedgwood and Sansom, 2003). In this study, openended offer format was used to calculate non-market economic value of recreational fishing. Within the $\mathrm{CV}$ analysis of the present study, respondents were asked if they are willing to pay for future improvements in the quality of recreational fishing activity in Ordu. Firstly, the quality of recreational fishing concept was hypothetically expressed to the respondents as follow: Increase in stock size, special recreational fishing areas, decrease in coastal pollution, organization of recreational fishers and recreational fishing tours. Then, the respondents were asked on their one time WTP to improve current situation. The hypothetical question was "Would you be willing to pay for future improved recreational fishing activity?" Respondents' mean WTP was determined, then, mean WTP was attributed to total number of recreational fishers to calculate total non-market economic value of recreational fishing in Ordu.

\section{Travel Cost Method}

A wide range of Travel Cost (TC) studies conducted for valuation of artificial marine habitats, recreational scuba diving aside from recreational fishing (Milon, 1988; Shrestha et al., 2002). TC model estimates was commonly based on count regression approaches which employs number of trips to a certain place as a dependent variable, whereas using independent variables as total travel expenditures, total travel time and demographics.

If $\mathrm{E}$ (TRIPS) $=\lambda_{i}$ is showed, general equation can be summarized as below (Equation 3 ):

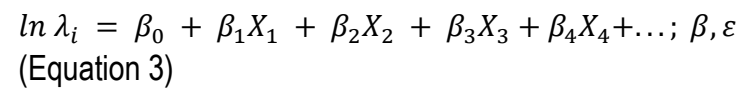

In the equation, TRIPSi is the number of trips by individual $i,\left(\lambda_{i}\right.$ also states number of trips taken by individual $i, \beta$ is the vector of parameters ( $\beta_{0}$ is the constant term, $\beta_{1}, \beta_{2}, \beta_{3}$ are coefficients of independent variables which include trip costs, demographic dimensions) and $\varepsilon$ is random error term.

Consumer surplus is found by using integral of recreational demand function (Equation $4 \& 5$ ).

$$
\begin{aligned}
& \int \lambda_{i} d p=\lambda_{i} / \beta \rrbracket(\text { Equation } 4) \\
& C S_{\text {per trip }}=\int_{T_{S}}^{T^{0}} \lambda_{i} d T=-\lambda_{i} / \beta_{T} \text { (Equation 5) }
\end{aligned}
$$

In the equations above, $C S_{\text {per trip }}$ represents individual consumer surplus for each trip, $T_{s}$, actual sample mean of each trip cost, $T^{0}$ is the choke recreation trip cost, $\beta_{T}$ is the estimator of individual trip cost variable on demand function and $\lambda_{i}$ is the expected latent quantity demand. Consumer surplus per fisher for each trip is calculated by $-1 / \beta_{T}$. By using this fraction, recreational consumer surplus can be calculated for sampled population. Then, it is generally expected to find out that there is a negative relation between number of trips and TC per trip.

In this study, zero-truncated negative binomial regression model because of the over-dispersed and truncated nature of the count data. Zero-truncated negative binomial regression was used to assess factors affecting trip data and to calculate consumer surplus of recreational fishers (Gillig et al., 2000; Winkelmann, 2000; Park et al., 2002; Shrestha et al., 2002; Bilgic and Florkowski, 2007). The most common form of truncation in over-dispersed count data is (left) truncation at zero. Truncated poisson and negative binomial models have been discussed, among others, by Creel and Loomis (1990) and Grogger and Carson (1991).

Mean and variance of the truncated at zero negative binomail model are given by $E_{t z}(y \mid \lambda, y>0)=\frac{\lambda}{1-(-\lambda)}$ (Equation 6) and

$$
\operatorname{Var}_{t z}(y \mid \lambda, y>0)=E(y \mid \lambda, y>0)\left(1-\frac{\lambda}{\exp (\lambda)-1}\right)
$$
(Equation 7).

Since $\lambda$ (the mean of the untruncated distribution) is greater than zero, $0<\exp (-\lambda)<1$ and the truncated mean is shifted to the right. Morover, the truncated-at-zero model displays underdispersion since $0<1-\lambda /(\exp (\lambda)-1)<1$ (Winkelmann, 2000).

\section{RESULTS}

\section{Demographics and Socioeconomics}

Results gathered from the questionnaire survey presented that recreational fishing activity in Ordu is a male dominant activity with a rate of $99.2 \%$ (119 individuals). The mean age of the respondents were determined as $35 \pm 9.9$ (minimum, 20; maximum, 60). Among the occupation of the respondents, public servants $(22.5 \%)$, national company workers $(18.3 \%)$, students $(15 \%)$, freely occupied persons $(15 \%)$, and retired persons $(13.3 \%)$ composed the majority. The most common education levels of respondents were 12 years high school education $(43.3 \%)$ whereas, the respondents who have bachelor's level (28.3\%) and 8 years secondary education level $(20.8 \%)$ composed the majority of rest. The monthly household income of the respondents was determined as 


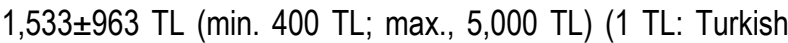
Liras $=0.37$ Euro, $2011 \mathrm{TL} /$ Euro Rates).

\section{Recreational Fishing Activity}

From the results activity related questions of in the survey, it was found that $21.7 \%$ of the respondents ( 26 individuals) had recreational fishing license; in addition, $70 \%$ of the respondents also attend hunting activities in the terrestrial zone. $16.7 \%$ of all respondents (20 individuals) was determined as boat-based recreational activities while the majority of respondents are shore-based activities including shore angling, speargun fishing and/or both. More than half of the respondents $(56 \%)$ are only using fishing rod and line for recreational fishing whereas the rest are using handlines, casting nets, fish spears or different combinations of all these gears. Average fishing experience of the respondents in years was determined as $10 \pm 7.2$ ( $\min$. 2; max., 35).

The main purposes of respondents to attend recreational fishing activity are having fun $(59 \%)$, doing sports $(14 \%)$ or both $(22 \%)$ whereas, the rest of respondents $(5 \%)$ aims a commercial value from fishing. Daytime preference for recreational fishing activity was afternoon (15.6\%), sunset $(16.2 \%)$ and any time of the day $(40.4 \%)$ which includes sunrise, noon, afternoon, sunset or night. In addition, individuals generally prefer to attend recreational fishing activity alone $(22.1 \%)$ and majority of the rest prefers to attend the activity with one $(53.2 \%)$ or two $(19.5 \%)$ individuals. Monthly preference of participation to a recreational fishing activity throughout the year is provided in Figure 2. High participation numbers of focus group was determined between June and October.

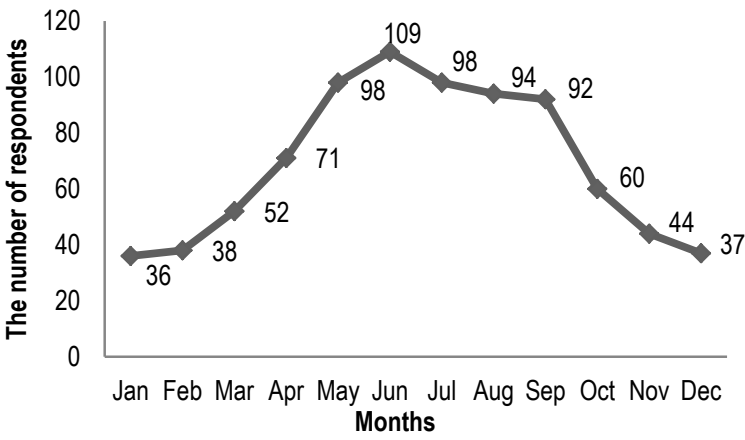

Figure 2. Participation to recreational fishing activity throughout the year ( $\mathrm{N}$ 120)

$95 \%$ of the respondents indicated that they consume the fish they caught. $94.2 \%$ of the respondents do not release the mature fish they caught whereas, $87.5 \%$ release back juvenile individuals and the rest $27.5 \%$ use the catch for other purposes like giving to relatives, neighbours or selling.

Respondents also assessed in terms of transport type and, majority of all the respondents prefer coming to the recreational fishing site on foot $(40 \%)$, and the rest uses public transport (20\%), own vehicle (18.3\%), bicycle $(15.8 \%)$, friends' vehicle $(5.8 \%)$. The average distance to the recreational fishing site was determined as $3 \pm 5.4 \mathrm{~km}$ with an average time spent, $10.3 \pm 8.1$ minutes.

$16.7 \%$ of all the respondents (20 individuals) stated that they also attend recreational fishing activity by boat. The mean number of boat-based recreational fishing days was determined as $35.3 \pm 34.2$ days ( $\min .5$; max. 120). The mean length and horse power of vessels, respectively, were calculated as $4.8 \mathrm{~m} \pm 1.4$ ( $\min .3$; $\max .8$ ), 12.6 Horse Power \pm 8.5 (min. 4; max. 32). Owners of the vessels were generally the recreational fishermen him/herself $(52.6 \%)$ or their friend $(36.8 \%)$. Yearly average repair-maintenance and fuel expenses of boat-based recreational fishing were determined as $61.1 \pm 83.5 \mathrm{TL}, 139 \pm 151.1 \mathrm{TL}$, respectively. The mean distance from the shoreline and the mean depth for boat-based recreational fishing was determined as $1.6 \pm 1$ nautical mile and $20.5 \pm 7.8 \mathrm{~m}$.

\section{Costs of Recreational Fishing}

The average yearly costs related to recreational fishing activity were determined as follow: Fishing equipment: 89.9 $122.2 \mathrm{TL}$ (min. $10 \mathrm{TL}$; max. $600 \mathrm{TL}$ ). Bait: $31.5 \pm 64.7 \mathrm{TL}$ (min. 0 TL; max. 400 TL). Transport: 30.7 \pm 68.9 TL (min. 0 TL; max. $500 \mathrm{TL}$ ). Seperately from the expenses done for fishing equipment, the average total economic value of fishing equipment was also calculated as $149 \pm 237.9 \mathrm{TL}$ ( $\mathrm{min} .10 \mathrm{TL}$; $\max .1,500 \mathrm{TL})$.

\section{Catch}

Daily mean amount of catch, $1.8 \pm 1.8 \mathrm{~kg}$ (min. $0.3 \mathrm{~kg}$; max. $10 \mathrm{~kg}$ ), daily maximum amount of catch $6 \pm 14.6 \mathrm{~kg}$ (min. $1 \mathrm{~kg}$; max. $150 \mathrm{~kg}$ ) and yearly mean amount of catch of all the respondents were calculated as $40 \pm 38.2 \mathrm{~kg}$ (min. $4 \mathrm{~kg}$; max. $200 \mathrm{~kg}$ ). Economic value and catch amounts of main species were given in Table 1.

In addition, total number of species caught 6 individuals (5\%) also indicated that they caught sturgeon (Acipenser sp.) or salmon (Salmo trutta spp.) species with a total catch of 14 $\mathrm{kg}$. 
Table 1. Main species' contribution to the total recreational fishing catch

\begin{tabular}{l|l|c|c|c|c}
\hline Family & Species & Share in Total Catch (\%) & Total Catch (kg) & Unit Price (TL/kg) & Market Value (TL) \\
\hline Moronidae & Dicentrarchus labrax & 32.2 & 2,774 & 28 & 77,672 \\
\hline Mugilidae & Mugil cephalus & 12.4 & 1,066 & 9 & 9,594 \\
\hline Mugilidae & Mugil soiuy & 12.1 & 1,043 & 9 & 9,387 \\
\hline Pomatomidae & Pomatomus saltator & 11 & 944 & 18 & 16,992 \\
\hline Sparidae & Sparus aurata & 7.3 & 624 & 43 & 26,832 \\
\hline Centracanthidae & Spicara flexuosa & 6 & 518 & 2 & 1,036 \\
\hline Sciaenidae & Sciaena umbra & 5.6 & 480 & 19 & 9,120 \\
\hline Sparidae & Diplodus vulgaris & 5 & 428 & 8 & 3,424 \\
\hline Carangidae & Trachurus trachurus & 2.9 & 250 & 4 & 1,000 \\
\hline Scorpaenidae & Scorpaena porcus & 2.2 & 185 & 20 & 3,700 \\
\hline Scombridae & Sarda sarda & 1.5 & 127 & 10 & 1,270 \\
\hline Gadidae & Merlangius merlangus & 0.9 & 75 & 3.5 & 262.5 \\
\hline Scophthalmidae & Scophthalmus maximus & 0.4 & 36 & 45 & 1,620 \\
\hline Gobiidae & Gobio spp. & 0.4 & 33 & 1 & 33 \\
\hline Mullidae & Mullus barbatus & 0.2 & 20 & 40 & 800 \\
\hline Total & & 100 & 8,603 & & $162,742.5$ \\
\hline
\end{tabular}

Table 2. Definitions and descriptive statistics of the variables used in the tobit regression and the zero-truncated negative binomial regression models

\begin{tabular}{|c|c|c|}
\hline Expressions & Variables & $\begin{array}{l}\text { Mean } \pm \text { Std.Dev.(Min.-Max) } \\
\text { or Percentage }\end{array}$ \\
\hline The ages of respondents in years & Age & $35 \pm 9.9(20-60)$ \\
\hline Marital status of the respondents (1:Married, $0:$ Single) & Marital Status & $70 \%: 84$ married persons \\
\hline $\begin{array}{c}\text { Education level of respondents (1:Uneducated, 2: Elementary School, } \\
\text { 3:Secondary (8 years) Middle School, 4:High School, 5:Bachelor's degree, } \\
\text { 6:Master's degree) }\end{array}$ & Education & $4 \pm 0.9(1-6)$ \\
\hline Monthly household income of the respondents (TL) & Income & $1,532.9 \pm 963.3(400-5,000)$ \\
\hline The respondents' ownership of a recreational fishing license (1:Yes, $0:$ No) & $\begin{array}{l}\text { Recreational Fishing } \\
\text { License }\end{array}$ & $20 \%: 24$ licensed persons \\
\hline Respondents' recreational fishing experience (in years) & Experience & $10 \pm 7.1(2-35)$ \\
\hline Respondents' daily average recreational fishing hours & $\begin{array}{l}\text { Recreational Fishing } \\
\text { Hours }\end{array}$ & $3.3 \pm 2(1-10)$ \\
\hline Economic value of respondents' fishing equipment (TL) & Gear Value & $149 \pm 237.9(10-1,500)$ \\
\hline $\begin{array}{l}\text { The distance between the respondents' residence and recreational fishing site } \\
\qquad(\mathrm{km})\end{array}$ & Distance & $3 \pm 5.4(0.3-35)$ \\
\hline The total amount of fish caught in last year $(2011)(\mathrm{kg})$ & Catch & $71.7 \pm 132(4-1,065)$ \\
\hline The total expense for fishing equipment in last year (TL) & Gear Expense & $89.9 \pm 122.2(10-600)$ \\
\hline The total expense for bait in last year (TL) & Bait Expense & $31.5 \pm 64.7(0-400)$ \\
\hline The mean amount of willingness to pay of respondents (TL) & Mean WTP & $10 \pm 13.5(0-50)$ \\
\hline Individual recreational fishing trip cost (TL) & Travel Cost & $4.5 \pm 4.6(0.2-30)$ \\
\hline Individual yearly recreational fishing days & $\begin{array}{l}\text { Recreational Fishing } \\
\text { Days }\end{array}$ & $40 \pm 38.2(4-200)$ \\
\hline Constant variables of the econometric models & Constante & - \\
\hline
\end{tabular}

Std. Dev., Standard Deviation; Min., Minimum; Max., Maximum

\section{Valuation of Recreational Fishing}

CVM and TCM were used to determine non-market economic value of recreational fishing in Ordu. Firstly, within the CV scenario, the WTP amounts of the respondents were determined using an open-ended question format. $50.8 \%$ of the respondents have WTP for an improvement in the quality of recreational fishing activities in Ordu. The descriptive statistics of the variables used in both tobit regression and zero-truncated negative binomial regression models were represented in Table 2.

Tobit regression analysis was used to demonstrate factors affecting the amount of WTP. The variables, Income,
Recreational Fishing Hours, Gear Value, and Bait Expense have positive relationship with the stated amount of WTP whereas Catch and Gear Expense have negative relationship (Table 3).

The average amount of WTP was determined as $10 \pm 13.5$ TL. The non-market economic value via CVM can be obtained as follow: The total number of licensed recreational fishers in Ordu was 630 . As considered the licensed recreational fishers among the respondents of present study (20\%: 24 persons), empirically, the estimation of total recreational fishers was calculated as 3,150 by proportioning. Then, via multiplying 3,150 by 10 , yearly non-market economic value of recreational fishing in Ordu Province can be calculated as 31,500 TL. 
In the travel cost model, to better understand nature of count data, recreational fishing days, mean and variance of recreational fishing days were calculated as $40 \pm 1,460$.6. The result showed that there is an over-dispersion in the count data. Alpha value in the result of the zero-truncated negative binomial regression model is significantly different from zero and thus, indicates that the Poisson distribution is not appropriate for this count data. In addition, histogram plot of the variable recreational fishing days showed a right skewness which also supports the use of zero-truncated negative binomial regression model (Table 3).

Zero-truncated negative binomial regression model was used to represent factors affecting the number of Recreational Fishing Days because of the over-dispersed and zerotruncated nature of the count data. The independent variables affecting the dependent variable, recreational fishing days, in the zero-truncated negative binomial regression were determined. Recreational Fishing License, Gear Value and Catch variables are positively correlated with the variable Recreational Fishing Days; however Education, Income and lastly as expected, TC variable negatively correlated with the variable Recreational Fishing Days (Table 3).

Table 3. Tobit regression and zero-truncated negative binomial regression models representing the independent variables affecting the dependent variables

\begin{tabular}{|c|c|c|c|c|}
\hline & & $\begin{array}{c}\text { Tobit } \\
\text { Regression }\end{array}$ & \multicolumn{2}{|c|}{$\begin{array}{l}\text { Zero-Truncated Negative } \\
\text { Binomial Regression }\end{array}$} \\
\hline $\begin{array}{l}\text { Independent } \\
\text { Variables }\end{array}$ & Coefficients & $\begin{array}{l}\text { Standard } \\
\text { Errors }\end{array}$ & Coefficients & $\begin{array}{l}\text { Standard } \\
\text { Errors }\end{array}$ \\
\hline Age & -0.45 & 0.30 & 0.01 & 0.01 \\
\hline Marital Status & 0.80 & 4.99 & 0.15 & 0.16 \\
\hline Education & -1.85 & 2.35 & $-0.14^{*}$ & .074 \\
\hline Income & $0.01^{* \star *}$ & 0.00 & $-0.00^{*}$ & 0.00 \\
\hline $\begin{array}{l}\text { Recreational } \\
\text { Fishing } \\
\text { License }\end{array}$ & 6.25 & 4.64 & $0.32^{* *}$ & 0.15 \\
\hline Experience & 0.29 & 0.45 & 0.00 & 0.01 \\
\hline $\begin{array}{c}\text { Recreational } \\
\text { Fishing Hours }\end{array}$ & $3.70^{* * *}$ & 0.98 & - & - \\
\hline Gear Value & $0.05^{\star \star \star}$ & 0.02 & $0.00^{*}$ & 0.00 \\
\hline Catch & $-0.089^{\star \star \star}$ & 0.03 & $0.00^{* \star *}$ & 0.00 \\
\hline Gear Expense & $-0.07^{\star *}$ & 0.03 & - & - \\
\hline Bait Expense & $0.10^{\star \star *}$ & 0.03 & - & - \\
\hline Distance & - & - & 0.02 & 0.01 \\
\hline Travel Cost & - & - & $-0.05^{\star * \star}$ & 0.02 \\
\hline Cons & -2.79 & 13.06 & 3.60 & 0.41 \\
\hline $\begin{array}{c}\text { Dependent } \\
\text { variable }\end{array}$ & \multicolumn{2}{|c|}{ Mean WTP } & \multicolumn{2}{|c|}{ Recreational Fishing Days } \\
\hline $\begin{array}{l}\text { Log } \\
\text { likelihood }\end{array}$ & \multicolumn{2}{|c|}{-285.32} & \multicolumn{2}{|c|}{-514.20} \\
\hline $\begin{array}{l}\text { Likelihood } \\
\text { Ratio Chi² } \\
\text { (11) }\end{array}$ & \multicolumn{2}{|c|}{69.23} & \multicolumn{2}{|c|}{83.89} \\
\hline Pseudo $\mathrm{R}^{2}$ & \multicolumn{2}{|c|}{0.11} & \multicolumn{2}{|c|}{0.08} \\
\hline Alpha & \multicolumn{2}{|c|}{-} & 0.32 & 0.04 \\
\hline $\begin{array}{c}\text { Number of } \\
\text { observations }\end{array}$ & \multicolumn{2}{|c|}{120} & \multicolumn{2}{|c|}{120} \\
\hline
\end{tabular}

*** Coefficient significant at $P \leq 0.01$ or better

** Coefficient significant at $P \leq 0.05$ or better

${ }^{*}$ Coefficient significant at $P \leq 0.10$ or better
To calculate consumer surplus, following function were used: Consumer Surplus $=-1 / \beta_{\text {T }}$ (Equation), then, Consumer Surplus $=-1 /-0.05=20$. Consumer surplus was calculated as $20 \mathrm{TL}$ for per recreational fisher in Ordu. $\beta_{\mathrm{T}}$ represents the coefficient of Travel Cost variable in the regression model. The exact number of recreational fishers is not known, therefore, as in the case of above calculation for contingent valuation, the total number of licensed anglers in Ordu can be considered to calculate economic value. There are currently 630 licensed recreational fishers in Ordu according to ministry records. By considering the recreational fishing days (40), estimated yearly total number of fishing days was calculated as 25,200 . Lastly, total attributed consumer surplus was calculated as multiplying 25,200 by $20 \mathrm{TL}$, and economic valuation result via TCM represents a total economic value of 504,000 TL.

\section{Conclusion And Discussion}

In this study, recreational fishing activity on the coasts of Ordu was assessed in terms of social, economic and biological impacts. There are different supporters for recreational fishing in Ordu including easy access to the coastal recreational fishing sites, existence of high diversity of economically important species (Table 1) and beside, developed and populated coastal counties like Perşembe, Fatsa and Ünye in addition to the city center.

According to the national statistics, total number of registered recreational fishermen in Ordu is 630 (TSI, 2011), but it is estimated that the real total number of recreational fishermen in Ordu is much higher than this value. However, owning a license is not compulsory to attend a recreational fishing activity in Turkey (Anonymous, 2012) which is maybe a forcing power to go fishing without any license.

Recreational fishing in Ordu is almost shore-based while, $16.7 \%$ of respondents (20 persons) attend boat-based recreational fishing activity averagely 35 days in a year. The considerable amount of expenses (yearly repair-maintenance: 61.1 TL and fuel: $139 \mathrm{TL}$ ) made by boat-based recreational fishing also indicates the local economic impact of recreational fishing in Ordu. Generally, average costs regarding the recreational fishing activity including fishing gear (89.9 TL), bait (31.5 TL) and transport (30.7 TL) were also significant to mention about their affect to local economy. In addition, the average total economic value of fishing equipment (149 TL) also indicates the degree of importance given to recreational fishing by respondents.

The respondents who mostly rated the quality of recreational fishing in Ordu as good seems to be satisfied because of considerable daily $(1.8 \mathrm{~kg})$ and yearly $(40 \mathrm{~kg})$ mean amount of catches and, there is also significant economic value of the economically important species caught (yearly total catch value of 120 respondents: $162,742.5 \mathrm{TL}$ with the total amount: 8,603 kg). 
Non-market economic value calculated via CVM $(31,500$ $\mathrm{TL})$ and TCM (504,000 TL) with 50.8\% acceptance rate for a WTP to an improvement in the quality of recreational fishing activities in Ordu. Economic valuation results indicated that there is a considerable amount of non-market economic value given by the respondents. Consistent with economic theory, as expected, the econometric model, zero-truncated negative binomial regression, represented the negative relationship between the number of recreational fishing trips and travel cost whereas, the amount of catch was determined as positively correlated with the number of recreational fishing trips. Mean CS estimates for the demand models are calculated by using negative inverse of TC coefficient $(-1 / \beta)$ (Shrestha et al., 2002; Bilgic and Florkowski, 2007).

The computed consumer surplus per trip was $\$ 161$ (Bilgic and Florkowski, 2007) and the average consumer surplus measure per day of $\$ 86.35$ to $\$ 138.91$ (Shrestha et al., 2002) were determined as much higher than the average consumer surplus estimations revealed from the synthesis of the past recreational fishing studies in the United States and elsewhere (Shrestha et al., 2002). However, the consumer surplus result obtained from this study via CVM (10 TL) and TCM (20 TL) showed similarity with the previous study conducted by Cantrell et al. (2004) in terms of calculated consumer surplus (US\$ 7.95). Moreover, the consumer surplus result $(25 \mathrm{TL})$ via $\mathrm{TC}$ method in the first valuation

\section{REFERENCES}

Anonymous, 2012. No: 3/2 Notification of regulations on marine and inland recreational fisheries in Turkey (in Turkish). Notification Number: 2012/66. Republic of Turkey Ministry of Food, Agriculture and Livestock Ankara.

Bateman, I., Willis, K.G., 2002. Valuing Environmental Preferences: Theory and Practice of Contingent Valuation Method in the US, EU and Developing Countries. Oxford University Press, USA. ISBN-10: 0199248915, $692 \mathrm{p}$.

Bilgic, A., Florkowski, W.J., 2007. Application of a hurdle negative binomia count data model to demand for bass fishing in the southeastern United States. Journal of Environmental Management, 83: 478-490. doi: 10.1016/j.jenvman.2006.10.009

Cantrell, R.N., Garcia, M., Leung, P., Ziemann, D., 2004. Recreationa anglers' willingness to pay for increased catch rates of Pacific threadfin (Polydactylus sexfilis) in Hawaii. Fisheries Research. 68: 149-158. doi: 10.1016/j.fishres.2004.01.003

Creel, M.D., Loomis, J.B., 1990. Theoretical and empirical advantages of truncated count data estimators for analysis of deer hunting in California. American Journal of Agricultural Economics, 72(2): 434-441. doi: $10.2307 / 1242345$

Demir, N., 2007. Ordu İlinin Eski Adı "kotyora" ve Tarihî Alt Yapısı, Turkish Studies, Volume $2 / 2$.

EU, 2004. Mediterranean: guaranteeing sustainable fisheries. Fishing in Europe, 21, $12 \mathrm{pp}$.

FIS, 2011. Fisheries Information System, Republic of Turkey Ministry of Food, Agriculture and Livestock, General Directorate of Fisheries, Ankara. Turkey.

Gaudin, C., De Young, C., 2007. Recreational fisheries in the Mediterranean countries: a review of existing legal frameworks. Studies and Reviews General Fisheries Commission for the Mediterranean. No.81. Rome, FAO. $85 \mathrm{pp}$ study on marine recreational fishing in Turkey by Tunca et al. (2012) is also determined as close to the result in the current study $(20 \mathrm{TL})$. In another study conducted by Loomis et al. (1999) estimated recreational fishing value of $\$ 32.83$ per person day in 1996 U.S. dollars using meta-analysis which is also similar to current study.

Consequently, recreational fishing is an important activity in Ordu by considering the great economic value and impact determined. Recreational fishing in Ordu has also a future potential to be improved in quality by supplying new services including recreational fishing tours, catch and release fishing, creation of recreational fishing organizations to disseminate and share recreational fishing knowledge, other ecotourism options and realistic management rules. Then, it may become helpful to increase both market and non-market benefits from recreational fishing. To conclude, this first snapshot regarding the recreational fishing benefits in Ordu can be a pathfinder for future recreational fishing valuation studies in the Black Sea region.

\section{ACKNOWLEDGEMENTS}

We would like to thank the recreational anglers who patiently answered questions and gave additional necessary information during the on-site face-to-face interviews in Ordu. Errors remain our responsibility.

Gillig, D., Ozuna, Jr.T., Griffin, W.L., 2000. The Value of the Gulf of Mexico Recreational Red Snapper Fishery. Marine Resource Economics, 15: 127-139.

Greene, W.H., 2000. Econometric Analysis, Prentice Hall, USA, 1004 p.

Grogger, J.T., Carson, R.T., 1991. Models for truncated counts. Journal of Applied Econometrics, 6: 225-238. doi: 10.1002/jae.3950060302

Gujarati, N.D., 2004. Basic Econometrics. McGraw-Hill, $4^{\text {th }}$ Edition, USA. 1002 p.

Haab, T.C., 2002. Valuing Environmental and Natural Resources, Econometrics of Non-Market Valuation, Edward Elgar Publishing Limited. 352 p. doi: $10.4337 / 9781843765431$

Hickley, P., Tompkins, H., 1998. Recreational Fisheries: Social, Economic and Management Aspects. Wiley-Blackwell, 1st Edition, 328 pp.

Loomis, J.B., Rosenberger, R., Shrestha, R.K., 1999. Updated Estimates of Recreation Values for the RPA Program by Assessment Region and Use of Meta-Analysis for Recreation Benefit Transfer. Final Report for the USDA Forest Service, Colorado State University, Fort Collins. 143 p.

Markovic, M., Satta, A., Skaricic, Z., Trumbic, I., 2009. Sustainable Coastal Tourism, An integrated planning and management approach, the Priority Actions Programme Regional Activity Centre (PAP/RAC). United Nations Environment Programme, Division of Technology, Industry and Economics (UNEP-DTIE) "Practical Manuals on Sustainable Tourism" publication series. $68 \mathrm{p}$.

Milon, J.W., 1988. Travel Cost Methods For Estimating The Recreational Use Benefits of Artificial Marine Habitat. Southern Journal of Agricultural Economics, $15 \mathrm{p}$.

Miran B., 2003. Basic Statistics. Ege University Press, ISBN 975-9308800, Bornova, İzmir, Turkey. 297 p.

Morales-Nin, B., Moranta, J., Garcia, C., Tugores, M.P., Grau, A.M., Riera, F., Cerda, M., 2005. The recreational fishery off Majorca Island (western Mediterranean): some implications for coastal resource management. 
ICES Journal of Marine Science, 62: 727-739. doi: 10.1016/j.icesjms.2005.01.022

Morales-Nin, B., Grau, A.M., Palmer, M., 2008. Managing coastal zone fisheries: interactions between small-scale and recreational activities, ICES CM2008/K:01, Theme Session K: Small scale and recreational fisheries surveys, assessment, and management. pp. 179.

NOAA. 2013. National Oceanic. Atmospheric Administration. Fisheries Economics of the United States. $<$ http://www.st.nmfs.noaa.gov/economics/publications/feus/fisheries_eco nomics_2011>. Mart 7, 2013.

Park, T., Bowker, J.M., Leeworthy, V.R., 2002. Valuing snorkeling visits to the Florida Keys with stated and revealed preference models. Journal of Environmental Management, 65: 301-312. doi: 10.1006/jema.2002.0552

Parkkila, K., Arlinghaus, R., Artell, J., Gentner, B., Haider, W., Aas, $\varnothing$., Barton, D., Roth, E., Sipponen, M., 2010. Methodologies for assessing socio-economic benefits of European inland recreational fisheries. EIFAC Occasional Paper. 46. Ankara. FAO. 112 pp.

Ramanathan, R., 1998. Introductory Econometrics with Applications. The Dryden Press, USA, 664 pp.
Shrestha, R.K., Seidl, A.F., Moraes, A.S., 2002. Value of recreational fishing in the Brazilian Pantanal: a travel cost analysis using count data models. Ecological Economics, 42: 289-299.

Steijn, S., Czerniak, P., Volckaert, A., Ferreira, M., Devilee, E., Huizer, T., Hofstede, R., 2012. Integrated Coastal Zone Management, Ourcoasts: Outcomes and Lessons Learned, Directorate-General Environment of the European Commission. $35 \mathrm{p}$.

TSI, 2011. Year Book of Turkish Fisheries Statistics. Turkish Statistics Association. Prime Ministry. Ankara.

Tunca, S., Ünal, V., Miran, B., 2012. A preliminary study on economic value of recreational fishing in Izmir Inner Bay, Aegean Sea (Turkey). Ege Journal of Fisheries and Aquatic Sciences, 29(2): 55-62.

Ünal, V., Acarlı, D., Gordoa, A., 2010. Characteristics of Marine Recreational Fishing in Çanakkale Strait (Turkey). Mediterranean Marine Science, 11(2), 315-330. doi: $10.12681 / \mathrm{mms} .79$

Wedgwood, A., Sansom, K., 2003. Willingness-to-pay surveys - a streamlined approach: Guidance notes for small town water services. WEDC, Loughborough University, UK, ISBN 184380014 4, 234 pp.

Winkelmann, R., 2000. Econometric Analysis of Count Data. 5th Edition. Springer, Heidelberg. 876 p. doi: 10.1007/978-3-662-04149-9 